\title{
Pembuatan dan Karakterisasi Antena Mikrostrip dengan Struktur Satu Feed Line Dipole Co-Planar Waveguide dan dua patch untuk Repeater WIFI Dua Arah
}

\author{
Esti Susiloningsih,* Yono Hadi Pramono, dan Ali Yunus Rohedi \\ Jurusan Fisika-FMIPA, Institut Teknologi Sepuluh Nopember \\ Kampus ITS Sukolilo, Surabaya 61111
}

\begin{abstract}
Intisari
Antena Mikrostrip dengan struktur satu feed line dipole Co-Planar Waveguide dan dua patch untuk repeater wifi dua arah telah difabrikasi dan karakterisasi. Parameter-parameter fisis yang dikarakterisasi meliputi VSWR (Voltage Standing Wave Ratio), Return Loss, dan pola radiasi. Substrat yang digunakan untuk fabrikasi antena adalah FR4 dengan permitivitas relatif 4,47. Ukuran antena yang digunakan adalah $70 \mathrm{~mm} \times 50 \mathrm{~mm} \times 3 \mathrm{~mm}$, dengan lebar feed line $3 \mathrm{~mm}$, CPW $2 \mathrm{~mm} \times 20 \mathrm{~mm}$, dipole $4 \mathrm{~mm} \times 30 \mathrm{~mm}$, patch $20 \mathrm{~mm} \times 70 \mathrm{~mm}$. Hasil karakterisasi Network Analyzer tipe HP 8753ES pada frekuensi kerja 2,460 GHz adalah return loss $-23,68 \mathrm{~dB}$, dan VSWR 1,140. Nilai VSWR yang mendekati 1 pada frekuensi kerja tersebut menunjukkan bahwa daya masukan ditransmisikan hampir keseluruhan ke udara dengan porsi kecil yang di refleksikan balik ke dalam osilator/generator pulsa. Sedangkan return loss yang dihasilkan antena $<-15 \mathrm{~dB}$ berada rentang nilai yang dapat diterima untuk komunikasi dua arah.
\end{abstract}

KATA KUNCI: antena mikrostrip, FR4, dipole, CPW

\section{PENDAHULUAN}

Antena adalah suatu alat untuk meradiasikan atau menerima gelombang radio atau didefinisikan juga sebagai suatu bentuk peralihan antara ruang bebas dan instrumen pemandu. Selain sebagai alat untuk mengirim atau menerima energi, antena juga digunakan untuk mengoptimalkan energi radiasi pada arah tertentu dan menekannya pada arah yang lain. Bentuk dan desain antena yang diharapkan adalah antena yang mempunyai gain yang tinggi, efisiensi tinggi bandwidth yang lebar, profil rendah, bobot yang ringan dan biaya murah [1]. Pada artikel ini dilaporkan fabrikasi dan karakterisasi antena mikrostrip struktur satu feed line dipole coplanar waveguide $(C P W)$ dan dua patch untuk repeater wifi dua arah.

\section{TEORI}

Antena mikrostrip adalah suatu antena yang terbuat dari strip (patch) logam yang sangat tipis $\left(\mathrm{t}<<\lambda_{\circ}\right.$, dengan $\lambda_{\circ}$ panjang gelombang di ruang hampa) yang diletakkan pada jarak pecahan kecil panjang gelombang $\left(\mathrm{h}<<\lambda_{\circ}\right.$ yang pada umumnya adalah $0,003 \lambda_{\circ} \leq \mathrm{h} \leq 0,005 \lambda_{\circ}$ ) di atas ground plane. Strip (patch) logam dipisahkan dari ground planenya oleh substrat dari bahan dielektrik dengan konstanta dielektrik biasanya dalam rentang $2,2 \leq \epsilon_{r} \leq 12$ [1]. Bentuk patch antena mikrostrip ditunjukkan Gambar 1, dengan $\mathrm{h}$ $=$ tebal substrat, $\mathrm{w}=$ lebar patch, $n \lambda_{g} / 2=$ panjang patch .

\footnotetext{
*E-MAIL: estisusiloningsih@yahoo.co.id
}

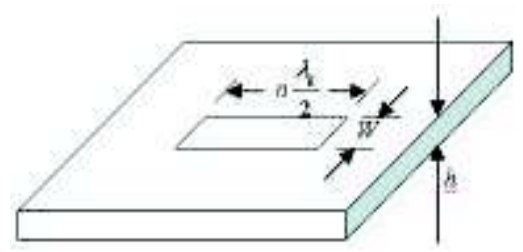

Gambar 1: Bentuk patch antenna mikrostrip

Antena mikrostrip meradiasikan gelombang elektromagnetik disebabkan karena terjadinya pass through medan listrik di sepanjang tepi antena. Medan ini akibat dari ketakkontinyuan saluran yang memberikan efek radiasi [2].

Standing waves dapat terjadi hanya jika frekuensi gelombang datang dan pantul sama. Perbandingan tegangan maksimum terhadap tegangan minimum disebut VSWR.

$$
\begin{aligned}
V S W R & =\frac{V_{\max }}{V_{\min }} \\
\operatorname{Returnloss}(d B) & =20 \log _{10}|\Gamma| \\
\Gamma & =10^{\left(-\frac{R L}{20}\right)}
\end{aligned}
$$

Impedansi masukan didefinisikan sebagai impedansi yang diberikan kepada rangkaian di luar oleh antenna pada suatu titik acuan tertentu, impedansi ini merupakan perbandingan tegangan dan arus atau perbandingan komponen medan listrik dan medan magnet yang sesuai dengan orientasinya. Impedansi masukan penting untuk pencapaian kondisi matching pada saat antena dihubungkan dengan sumber tegangan, sehingga semua sinyal yang dikirim ke antena akan terpancarkan. Pada antena penerima, jika kondisi matching tercapai, energi yang diterima antena akan bisa dikirimkan ke receiver. 

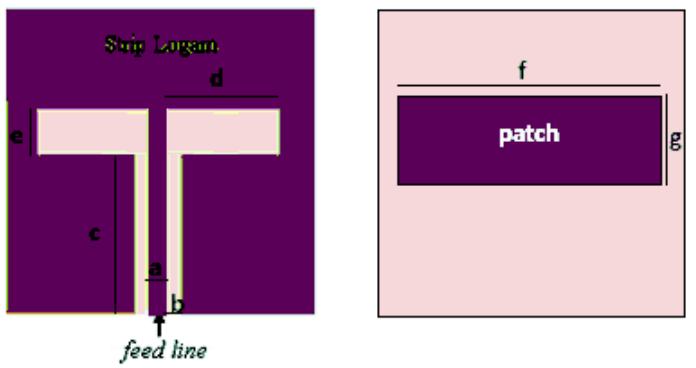

Gambar 2: Bentuk antena mikrostrip dengan struktur satu dipole CPW (a)

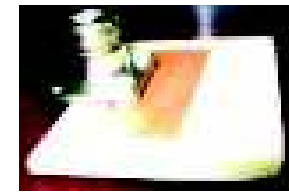

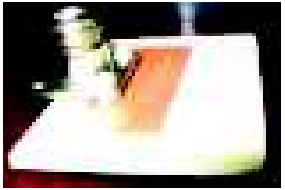

(b)
Gambar 3: Hasil pembuatan antena mikrostrip dengan struktur satu dipole CPW dan dua patch.

\section{METODOLOGI}

Peralatan dan bahan yang digunakan pada pembuatan dan pengujian antena adalah PCB dengan substrat FR4 single side dan double side dengan konstanta dielektrik 4,47, serta Network Analizer. Bentuk geometri antena mikrostrip ditunjukkan Gambar 2, dengan ukuran a $=3 \mathrm{~mm}, \mathrm{~b}=2 \mathrm{~mm}$, c $=20 \mathrm{~mm}, \mathrm{~d}=30 \mathrm{~mm}, \mathrm{e}=4 \mathrm{~mm}, \mathrm{f}=65 \mathrm{~mm}, \mathrm{~g}=20 \mathrm{~mm}$.

Antena mikrostrip dengan struktur satu feed line dipole Co Planar Waveguide dengan dua patch terdiri dari single side dan double side. patch pertama dibuat dibagian atas antena pada lapisan single side, feed line dipole $C P W$ dibuat di bagian atas pada lapisan double side dan dibagian bawahnya adalah patch kedua.

Hasil pembuatan antena mikrostrip struktur satu dipole CPW dan dua patch dapat dilihat pada Gambar 3. Antena mikrostrip dihubungkan ke port transmitter dari Network Analyzer dan bagian port out-put dihubungkan ke port receiver (Gambar 4). Pengukuran pola radiasi dilakukan di Laboratorium Optik dan Optoelektronik, Jurusan Fisika, FMIPAInstitut Teknologi Sepuluh Nopember Surabaya.

\section{HASIL DAN PEMBAHASAN}

Dari fabrikasi antena dengan struktur feed line dipole coplanar waveguide (CPW) dilakukan pengukuran di Laboratorium Gelombang Mikro, PENS ITS. Pada penelitian ini dibuat sebuah antena dengan slot dipole. Dapat dilihat dari grafik pada Gambar 5 diketahui bahwa antena bekerja baik pada frekuensi $2460 \mathrm{MHz}$ dengan return loss sebesar -23,68 dB. Nilai return loss yang semakin kecil, mengindikasikan sinyal yang direfleksikan semakin kecil sehingga sinyal yang

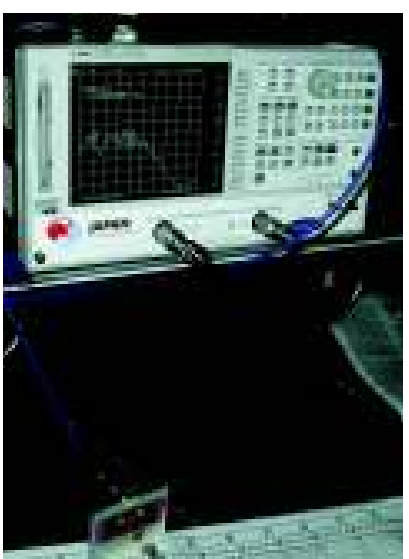

Gambar 4: Rangkaian pengukuran menggunakan Network Analizer tipe Agilent HP 8735 ES.

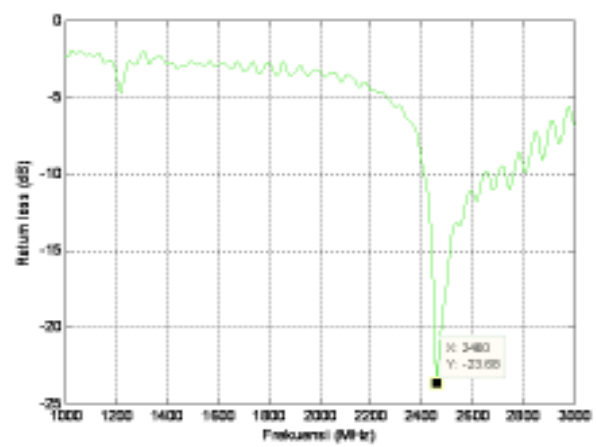

(a)

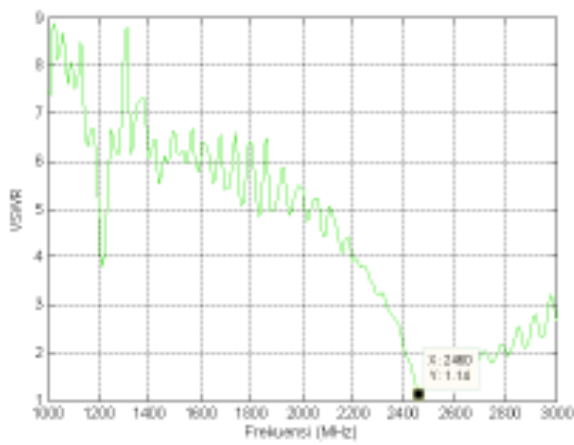

(b)

Gambar 5: Grafik nilai Return Loss terhadap frekuensi dan nilai VSWR dengan frekuensi

diteruskan semakin besar. Secara sederhana dapat di simpulkan dengan nilai return loss yang semakin kecil kinerja antena semakin bagus. Sedangkan nilai VSWR sebesar 1,14. Nilai VSWR yang mendekati 1 mengindikasikan bahwa kinerja antena semakin baik. 


\section{SIMPULAN}

Hasil pengukuran pada frekuensi kerja $2460 \mathrm{MHz}$ didapatkan nilai return loss sebesar $-23,68 \mathrm{~dB}$ dan nilai VSWR sebesar 1,14 sedangkan lebar pita frekuensi $290 \mathrm{MHz}$ pada range frekuensi $2410 \mathrm{MHz}$ hingga $2700 \mathrm{MHz}$.
[1] Balanis, C. A, antena Theory Analysis and Design (Second edition, John Wiley \& Sons, New York, 1997).

[2] Edwards, T., Foundations For Microstrip Circuit Design (Second edition, John Wiley and Son, Inc Canada, 1995).

[3] Hund, E., Microwave Communications, Component and Circuit (McGraw-Hill, New York, 1989).

[4] Mufadliyah, Fabrikasi Antena Folded Dipole Dengan Reflektor Parabola Untuk Frekuensi 2,4 GHz, Magister Thesis Program Pascasarjana Fisika, FMIPA-Institut Teknologi Sepuluh November Surabaya, 2007.

[5] Sari, N., Pembuatan Antena Mikrostrip Kombinasi Antara patch dan Slot Dengan Substrat FR4 Untuk Frekuensi Kerja 2,4 GHz,
Magister Thesis Program Pascasarjana Fisika, FMIPA-Institut Teknologi Sepuluh Nopember Surabaya, 2007.

[6] Sembada, A.M., Pembuatan Antena Mikrostrip 2,4 GHz Untuk Komunikasi Aironet Komputer, Magister Thesis Program Pascasarjana Fisika, FMIPA-Institut Teknologi Sepuluh Nopember Surabaya, 2006.

[7] Young, L., Haider, S., Neve, M.,Microstrip patch antennas for Broadband Indoor Wireless System, Part 4 Project Report, Department of Electrical \& Electronics Engineering, The University of Auckland Faculty of Engineering, 2003. 